\title{
Establishing a carbon stock baseline for the degraded vegetation in Cam Pha city, Quang Ninh province
}

\author{
Xây dưng đường cacbon cơ sở cho thảm thực vật thoái hóa ở thành phố Cẩm \\ Phả, tỉnh Quảng Ninh \\ Research paper \\ Nguyen The Hung ${ }^{*}$; Vu Thi Thanh Huong ${ }^{2}$. \\ ${ }^{1}$ Department of Climate Change, Hanoi University of Environment and Natural Resources, 41 A Phu Dien str., Hanoi, \\ Vietnam; ${ }^{2}$ Department of Biology, College of Education - Thai Nguyen University, Luong Ngoc Quyen str., Thai Nguyen, \\ Vietnam
}

\begin{abstract}
In Cam Pha city (Quang Ninh province) there existes a lot of vegetation having a high degree of degradation. Findings of the research plots located in 4 years $(2012-2015)$ have shown that, vegetation IC has the largest biomass (biomass fresh: 78.70 tons / ha; dry biomass: 36.65 tons / ha), followed by the grass vegetation (fresh biomass: 62.08 tons / ha; dry biomass: 25.67 tons / ha ). Vegetation IA has the lowest biomass (biomass fresh: 33.73 tons / ha; dry biomass: 15.18 tons / ha). The average amount of accumulated carbon in the biomass of vegetation IC is 18.33 tones / ha, in that vegetation IA was 7.60 tones/ ha, in the grass vegetation is 12.84 tones / ha. During the ecological succession, vegetation IC showed an increase in the ability to accumulate carbon (the amount of biomass carbon accumulation of vegetation IC in the $4^{\text {th }}$ year was 21.97 tons / ha). In addition, the paper also proposed the suitable methods of using degraded vegetation in Cam Pha city, Quang Ninh province.
\end{abstract}

Ở thành phố Cẩm Phả, tỉnh Quảng Ninh tồn tại nhiều thảm thực vật có mức độ thoái hóa cao. Kết quả nghiên cứu trong các ô nghiên cứu định vị trong 4 năm (2012 - 2015) cho thấy, thảm cây bụi IC có sinh khối lớn nhất (sinh khối tuơi: 78,70 tấn/ha; sinh khối khô: 36,65 tấn/ha), tiếp đến là thảm cỏ (sinh khối tuooi: 62,08 tấn/ha; sinh khối khô: 25,67 tấn/ha). Thảm cây bụi IA có sinh khối thấp nhất (sinh khối tuooi: 33,73 tấn/ha; sinh khối khô: 15,18 tấn/ha). Giữa các thảm thưc vật này còn khác nhau về cấu trúc sinh khối và tỷ lệ sinh khối khô / sinh khối tuơi. Lương cacbon trung bình đuợc tích lũy trong sinh khối của thảm thực vật cây bui IC là 18,33 tấn/ha, ở thảm cây bụi IA là 7,60 tấn/ha, ở thảm cỏ là 12,84 tấn/ha. Trong quá trình diễn thế, thảm cây bui IC có sư tăng lên về khả năng tích lũy cacbon (Luợng cacbon được tích lũy trong sinh khối của thảm cây bưi IC ở năm thư 4 là 21,97 tấn/ha). Ngoài ra, bài báo còn đề xuất phuoong thức sử dụng hợp lý các thảm thực vật thoái hóa ở thành phố Cẩm Phả, tỉnh Quảng Ninh.

Keywords: baseline of carbon, vegetation, degraded vegetation, accumulation of carbon, emission reduction, Cam Pha

\section{Introduction}

At present, a significant number of CDM projects's activities has been implemented in Vietnam, in which afforestation and reforestation are considered the most appropriate use of land. However, one of the strict requirements of $\mathrm{CDM}$ afforestation/reforestation projects is to determine their carbon stock baselines.
In Quang Ninh in general and in Cam Pha city in particular, many types of vegetation with high degree of degradation have existed. People have used the vegetation for different purposes and with various forms. However, no research has been done so far to develope a carbon stock baseline for the degraded vegetation here. 
This paper introduces results of a research determining carbon volume accumulated in biomass of the degraded vegetation and establishing their carbon baselines in Cam Pha city, Quang Ninh province.

\section{Materials and methods}

\subsection{Materials}

Types of vegetation in Cam Pha city, Quang Ninh province (vegetation $I C$, vegetation $I A$ and grass vegetation).

Biomass of vegetation is the organic material synthesized by plant species (both above- and below-ground), and litter.

Vegetation IC, IA and grass vegetation include various plant species in different biomass structures. In case of timber trees, they are usually in small size. Thus, the biomass of this vegetation is specified for all, not only for each individual species. The biomass of timber tree species having a diameter of $6 \mathrm{~cm}$ and higher is calculated for the vegetation based on their average density.

\subsection{Methods}

Basic steps in establishing carbon baseline for vegetation showed in Figure 1

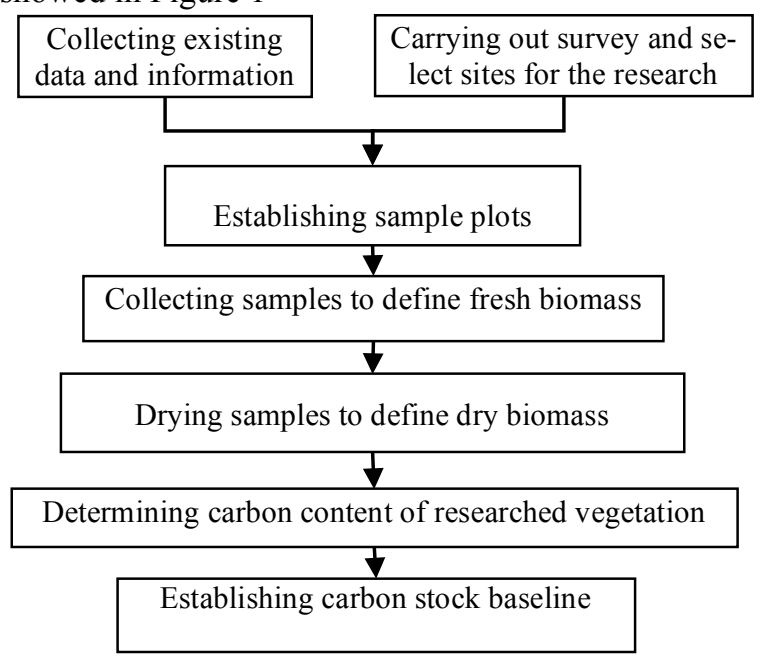

Figure 1: Diagram of steps for establishing carbon stock baseline

\subsubsection{Vegetation classification}

Vegetation in Cam Pha city, Quang Ninh province is degraded (tree canopy density less than 0.3 ), derived from forest vegetation and classified according to Loeschau's system (1963). This classification system is used by the Ministry of Agriculture and Rural Development in regulating criteria for forest identification and classification [2]. Degraded vegetation here is divided into 3 types: (i) Vegetaion IC: mainly covered by regenerated tree, density of more than 1 meter-regenerated trees being from 1000 trees/ha or more. (ii) Vegetation IA: tree canopy density not exceeding $10 \%$, main species including low bushes, without or with very few regenerated trees. (iii) Grass vegetation: may include some scattered growing small trees and bushes, but mainly still plants of Poaceae (typical height of 2-2.5m) such as - Saccharum arundinaceum Retz,
Thysanolaena maxima (Roxb.) Kuntze, Miscanthus floridulus (Labill.) Warb. ex Shum. et Lauterb., Imperata cylindrica (L.) P. Beauv.

\subsubsection{Sample plot}

For bushy vegetation, one sample plot has an area of $100 \mathrm{~m}^{2}$ $(10 \mathrm{~m} \times 10 \mathrm{~m})$. In each sample plot, 09 smaller square plots of $4 \mathrm{~m}^{2}$ per each $(2 \mathrm{mx} 2 \mathrm{~m})$ were established to identify fresh biomass of bushes and living vegetation (Figure 2). Names of plant species were mainly defined according to Pham Hoang Ho (1991 - 1993) [4] and Nguyen Tien Ban (1997) [1].

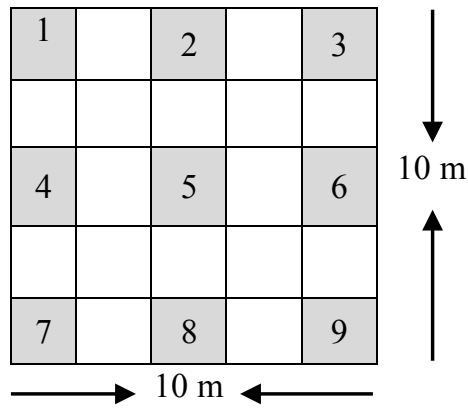

Figure 2: Arrangement of smaller square plots in sample plots

\subsubsection{Biomass measurement}

For fresh biomass: At each smaller square plot, all bushes, small trees and grass were cut at ground level, and then parts (stems, branches and leaves) of bushes and small trees and grass species were separated right in the field to determine fresh biomass. Litter was gathered into smaller square plots of $1 \mathrm{~m}^{2}(1 \mathrm{~m} \times 1 \mathrm{~m})$. As soon as the above-ground biomass was calculated, the whole roots in the area of $1 \mathrm{~m}^{2}$ $(1 \mathrm{~m} \times 1 \mathrm{~m})$ were dug up and collected. Soil and stone mixed in these roots were removed, cleaned and left to dry. Biomass of the collected samples was calculated with scale (being accurate to $0.1 \mathrm{gr}$ ).

For dry biomass: Randomly select around $10 \%$ of volume of each part, dry at the temperature of $105^{\circ} \mathrm{C}$, then repeatedly weigh them until the volume showed no change.

Moisture content of each portion of samples (leaves, stems, branches, grass, litter, roots) is calculated by the formula: $\mathrm{MC}(\%)=\{(\mathrm{FW}-\mathrm{DW}) / \mathrm{FW}\} \times 100$, in which:

$$
\begin{aligned}
& +M C \text { is the moisture content of the sample (\%) } \\
& +F W \text { is the fresh weight of the sample } \\
& +D W \text { is the dry weight of the sample. }
\end{aligned}
$$

Dry biomass of each portion (ton/ha) is calculated by the formula:

Dry biomass of leaves: $\mathrm{TDM}_{(\mathrm{l})}=\mathrm{TFW}_{(\mathrm{l})} \times\left(1-\mathrm{MC}_{(\mathrm{l})}\right)$ Dry biomass of stems, branches: $\mathrm{TDM}_{(\mathrm{tc})}=\mathrm{TFW}_{(\mathrm{tc})} \times(1-$ $\left.\mathrm{MC}_{(\mathrm{tc})}\right)$

Dry biomass of grass: $\operatorname{TDM}_{(\mathrm{c})}=\mathrm{TFW}_{(\mathrm{c})} \times\left(1-\mathrm{MC}_{(\mathrm{c})}\right)$ Dry biomass of litter: $\mathrm{TDM}_{(\mathrm{tm})}=\mathrm{TFW}_{(\mathrm{tm})} \times\left(1-\mathrm{MC}_{(\mathrm{tm})}\right)$ Dry biomass of roots: $\mathrm{TDM}_{(\mathrm{r})}=\mathrm{TFW}_{(\mathrm{r})} \times\left(1-\mathrm{MC}_{(\mathrm{r})}\right)$ 
In which: TFW(1), TFW(tc), TFW(c), TFW(tm), TFW (r) are respectively total fresh biomass of leaves, stems, grass litter and roots; $\mathrm{MC}_{(\mathrm{l})}, \mathrm{MC}_{(\mathrm{tc})}, \mathrm{MC}_{(\mathrm{c})}, \mathrm{MC}_{(\mathrm{tm})}, \mathrm{MC}(\mathrm{r})$ are respectively moisture content of leaves, stems, grass litter and roots.

The total biomass of the vegetation: TDB (tons/ha) = $\mathrm{TDM}_{(\mathrm{l})}+\mathrm{TDM}_{(\mathrm{tc})}+\mathrm{TDM}_{(\mathrm{c})}+\mathrm{TDM}_{(\mathrm{tm})}+\mathrm{TDM}_{(\mathrm{r})}$

Carbon biomass accumulated in biomass of the vegetation: $\mathrm{CS}=\left(\mathrm{TDM}_{(\mathrm{l})}+\mathrm{TDM}_{(\mathrm{tc})}+\mathrm{TDM}_{(\mathrm{c})}+\mathrm{TDM}_{(\mathrm{m})}+\mathrm{TDM}_{(\mathrm{r})}\right) \times 0,5$ (tons of $\mathrm{C} / \mathrm{ha}$ ), in which: 0,5 is the default factor set by Intergovernmental Panel on Climate Change (IPCC, 2005) [5]

Establishing carbon stock baseline: Data were processed with Microsoft Excel and SPSS.

\section{Results and discussion}

\subsection{Biomass of vegetation}

The determination of fresh biomass of the vegetation was carried out right in the field on sample plots. Fresh aboveground biomass of the vegetation is divided into fresh biomass of bushes and small wood plants (stems and leaves), fresh biomass of grass and biomass of natural litter. Fresh underground biomass of the vegetation is fresh biomass of their roots.

Dry biomass of the vegetation is also splited into dry biomass of bush + small woody plants, dry biomass of grass and dry biomass of litter and the one of roots.

Fresh and dry biomass of the vegetation are respectively as follows: vegetation IC (78.70 tons/ha; 36.65 tons/ha), vegetation IA (33.73 tons/ha; 15,18 tons/ha), Grass vegetation (62.08 tons/ha; 25.67 tons/ha) (Table 1, Figure 3).

Table 1. Biomass of the degraded vegetation in Cam Pha city, Quang Ninh province

\begin{tabular}{|c|c|c|c|c|c|c|c|c|c|}
\hline \multirow[b]{2}{*}{ Time } & \multirow{2}{*}{$\begin{array}{l}\text { Biomass } \\
\text { (tons } \\
\text { /ha) }\end{array}$} & \multicolumn{5}{|c|}{ Above ground } & \multirow{2}{*}{$\begin{array}{c}\text { Underground } \\
\text { Root }\end{array}$} & \multicolumn{2}{|c|}{ Total biomass } \\
\hline & & Stems & Leaves & Grass & Litter & Total & & $\begin{array}{l}\text { Biomass } \\
\text { (tons /ha) }\end{array}$ & $\begin{array}{c}\text { Ratio of dry } \\
\text { biomass/ fresh } \\
\text { biomass (\%) }\end{array}$ \\
\hline \multicolumn{10}{|c|}{ Vegetation IC } \\
\hline \multirow{2}{*}{2012} & Fresh & 23.91 & 6.27 & 6.5 & 9.2 & 45.88 & 21.4 & 67.28 & \multirow{2}{*}{44.4} \\
\hline & Dry & 11.07 & 2.1 & 2.21 & 5.07 & 20.45 & 9.39 & 29.84 & \\
\hline \multirow{2}{*}{2013} & Fresh & 25.9 & 8.34 & 6.3 & 9.9 & 50.44 & 24.6 & 75.04 & \multirow{2}{*}{46.0} \\
\hline & Dry & 14.54 & 2.33 & 2.2 & 5.14 & 24.21 & 10.33 & 34.54 & \\
\hline \multirow{2}{*}{2014} & Fresh & 30.6 & 9.94 & 6.9 & 9.6 & 57.04 & 24.9 & 81.94 & \multirow{2}{*}{46.7} \\
\hline & Dry & 16.8 & 2.65 & 2.34 & 5.28 & 27.07 & 11.19 & 38.26 & \\
\hline \multirow{2}{*}{2015} & Fresh & 36.2 & 11.99 & 6.09 & 11.07 & 65.35 & 25.19 & 90.54 & \multirow{2}{*}{48.5} \\
\hline & Dry & 19.9 & 3.99 & 2.02 & 6.69 & 32.60 & 11.34 & 43.94 & \\
\hline \multirow{2}{*}{ Average } & Fresh & 29.15 & 9.14 & 6.45 & 9.94 & 54.68 & 24.02 & 78.70 & \multirow{2}{*}{46.6} \\
\hline & Dry & 15.58 & 2.77 & 2.19 & 5.55 & 26.09 & 10.56 & 36.65 & \\
\hline \multicolumn{10}{|c|}{ Vegetation IA } \\
\hline \multirow{2}{*}{2012} & Fresh & 9.95 & 4.74 & 2.78 & 4.4 & 21.87 & 12.27 & 34.14 & \multirow{2}{*}{44.1} \\
\hline & Dry & 4.28 & 1.52 & 1.15 & 2.54 & 9.49 & 5.57 & 15.06 & \\
\hline \multirow{2}{*}{2013} & Fresh & 9.97 & 4.59 & 2.81 & 4.41 & 21.78 & 12.11 & 33.89 & \multirow{2}{*}{45.0} \\
\hline & Dry & 4.35 & 1.58 & 1.2 & 2.5 & 9.63 & 5.61 & 15.24 & \\
\hline \multirow{2}{*}{2014} & Fresh & 9.52 & 4.41 & 3.08 & 4.5 & 21.51 & 11.6 & 33.11 & \multirow{2}{*}{45.3} \\
\hline & Dry & 4.12 & 1.74 & 1.36 & 2.45 & 9.67 & 5.32 & 14.99 & \\
\hline \multirow{2}{*}{2015} & Fresh & 9.66 & 4.45 & 2.81 & 4.49 & 21.41 & 12.32 & 33.73 & \multirow{2}{*}{45.7} \\
\hline & Dry & 4.21 & 1.74 & 1.33 & 2.51 & 9.79 & 5.63 & 15.42 & \\
\hline \multirow{2}{*}{ Average } & Fresh & 9.78 & 4.55 & 2.87 & 4.45 & 21.65 & 12.08 & 33.73 & \multirow{2}{*}{45.0} \\
\hline & Dry & 4.24 & 1.65 & 1.26 & 2.5 & 9.65 & 5.53 & 15.18 & \\
\hline Grass veg & etaion & & & & & & & & \\
\hline 2012 & Fresh & 5.09 & 1.57 & 25.02 & 6.8 & 38.48 & 20.37 & 58.85 & 401 \\
\hline 2012 & Dry & 2.23 & 0.54 & 8.73 & 4.05 & 15.55 & 8.03 & 23.58 & 40.1 \\
\hline & Fresh & 5.13 & 2.34 & 25.55 & 7.4 & 40.42 & 21.27 & 61.69 & \\
\hline 2013 & Dry & 2.56 & 0.83 & 9.32 & 4.34 & 17.05 & 8.27 & 25.32 & 41.0 \\
\hline & Fresh & 7.03 & 2.84 & 26.14 & 7.9 & 43.91 & 21.79 & 65.70 & \\
\hline 2014 & Dry & 3.42 & 1.14 & 9.2 & 4.52 & 18.28 & 8.7 & 26.98 & 41.1 \\
\hline 2015 & Fresh & 5.15 & 2.54 & 25.54 & 8.7 & 41.93 & 20.17 & 62.10 & 431 \\
\hline 2015 & Dry & 2.25 & 0.93 & 9.25 & 5.01 & 17.44 & 9.3 & 26.74 & 43.1 \\
\hline & Fresh & 5.6 & 2.32 & 25.56 & 7.7 & 41.18 & 20.9 & 62.08 & 413 \\
\hline Average & Dry & 2.62 & 0.86 & 9.13 & 4.48 & 17.09 & 8.58 & 25.67 & 41.3 \\
\hline
\end{tabular}




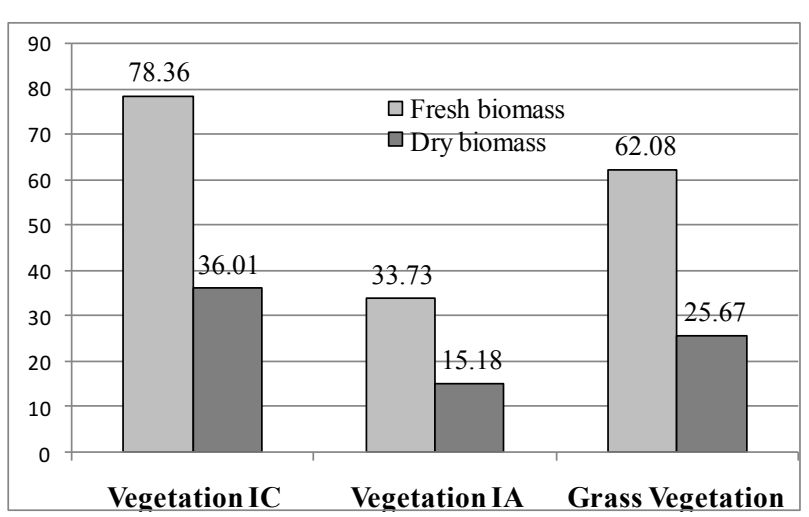

Figure 3. Fresh and dry biomass of the degraded vegetation in Cam Pha city, Quang Ninh province (tons/ha)

There are differences in biomass structure, proportion of dry biomass and fresh biomass (\%). At vegetation $I A$, biomass is mainly concentrated in roots. At Grass vegetation, it is in grass while biomass of vegetation $I C$ is concentrated in stems and branches (Table 1, Figure 4).

The proportion (\%) of dry biomass compared to that of dry biomas in vegetation IC and IA is relatively high and there is no noticeble difference $(45.0 \%-46.0 \%)$. However, this number is smaller for grass vegetation $(41.3 \%)$. Obviously, this ratio is affected by species composition in the community.

\subsubsection{Vegetation IC}

During the ecological succession, there was an obvious increase in fresh and dry biomass of vegetation IC over time (In 2012: fresh biomass: 67.28 tons/ha; dry biomass 29.84 tons/ha; In 2013: fresh biomass: 75.04 tons/ha; dry biomass: 34.54 tons/ha; In 2014: dry biomass: 81.94 tons/ha; dry biomass: 38.26 tons/ha; In 2015: fresh biomass: 89.17 tons/ha; dry biomass: 41.39 tons/ha).

\subsubsection{Vegetation IA}

Fresh biomass and dry biomass of vegetation IA did not show significant changes over time. From 2012 to 2015, the total fresh biomass was respectively as follows: 34.14 tons / ha -33.89 tons /ha -33.11 tons /ha -33.73 tons /ha; total dry biomass: 15.06 tons /ha -15.24 tons/ha -1.99 tons /ha - 15.42tons /ha) (Table 1).

Averagely, the dry biomass structure of vegetation $I A$ is as follows: stems, branches: 4.24 tons /ha; leaves:1.65 tons /ha; grass: 1.26 tons /ha; litter: 2.50 tons /ha; and roots: 5.53 tons /ha.

\subsubsection{Grass vegetation}

As of biomass structure of grass vegetation, herbaceous plants had the highest proportion of biomass with the fresh biomass reaching 25.56 tons/ha $(41.17 \%)$, dry biomass 9.13 tons/ha $(35.57 \%)$. Fresh biomass of other portions ranged from 2.32 đến 20.9 tons/ha and dry biomass from $0,86-8,58$ tons/ha (Table 1$)$.

There was no remarkable changes in biomass of Grass vegetation over time (Fresh biomass: 58.85 tons /ha (in 2012) $\rightarrow 61.69$ tons /ha (in 2013) $\rightarrow 65.70$ tons /ha (in 2014) $\rightarrow$ 62.10 tons/ha (in 2015); Dry biomass: 23.58 tons /ha (in $2012) \rightarrow 25.32$ tons $/$ ha (in 2013) $\rightarrow 26.98$ tons /ha (in $2014) \rightarrow 26.74$ tons $/$ ha (in 2015) (Table 1).

\subsection{Carbon stock in biomass of the vegetation}

Carbon volume accumulated in the vegetation biomass was determined based on dry biomass of portions (Table 2)

Table 2. Carbon volume accumulated in the biomass of the degraded vegetation in Cam Pha city, Quang Ninh district

\begin{tabular}{|c|c|c|c|c|c|c|c|c|}
\hline \multirow{2}{*}{$\begin{array}{c}\text { Type of Vegeta- } \\
\text { tion }\end{array}$} & \multirow{2}{*}{ Year } & \multicolumn{5}{|c|}{ Above ground (tons /ha) } & \multirow{2}{*}{$\begin{array}{l}\text { Underground } \\
\text { tons/ha) }\end{array}$} & \multirow{2}{*}{ Total } \\
\hline & & Stems & Leaves & Grass & Litter & Total & & \\
\hline \multirow{5}{*}{ Vegetation IC } & 2012 & 5.54 & 1.05 & 1.11 & 2.54 & 10.23 & 4.70 & 14.93 \\
\hline & 2013 & 7.27 & 1.17 & 1.10 & 2.57 & 12.11 & 5.17 & 17.28 \\
\hline & 2014 & 8.40 & 1.33 & 1.17 & 2.64 & 13.54 & 5.60 & 19.14 \\
\hline & 2015 & 9.95 & 2.00 & 1.01 & 3.35 & 16.30 & 5.67 & 21.97 \\
\hline & Average & 7.79 & 1.39 & 1.10 & 2.78 & 13.05 & 5.28 & 18.33 \\
\hline \multirow{5}{*}{ Vvegetation $1 A$} & 2012 & 2.14 & 0.76 & 0.58 & 1.27 & 4.75 & 2.79 & 7.54 \\
\hline & 2013 & 2.18 & 0.79 & 0.60 & 1.25 & 4.82 & 2.81 & 7.63 \\
\hline & 2014 & 2.06 & 0.87 & 0.68 & 1.23 & 4.84 & 2.66 & 7.50 \\
\hline & 2015 & 2.11 & 0.87 & 0.67 & 1.26 & 4.90 & 2.82 & 7.71 \\
\hline & Average & 2.12 & 0.83 & 0.63 & 1.25 & 4.83 & 2.77 & 7.60 \\
\hline \multirow{5}{*}{ Grass vegetation } & 2012 & 1.12 & 0.27 & 4.37 & 2.03 & 7.78 & 4.02 & 11.80 \\
\hline & 2013 & 1.28 & 0.42 & 4.66 & 2.17 & 8.53 & 4.14 & 12.67 \\
\hline & 2014 & 1.71 & 0.57 & 4.60 & 2.26 & 9.14 & 4.35 & 13.49 \\
\hline & 2015 & 1.13 & 0.47 & 4.63 & 2.51 & 8.72 & 4.65 & 13.37 \\
\hline & Average & 1.31 & 0.43 & 4.57 & 2.24 & 8.55 & 4.29 & 12.84 \\
\hline
\end{tabular}


Vegetation IA had very low carbon stock (7.60 tons/ha) while this number in Vegetation IC was 10.01 tons/ha, in grass vegetation was 12.84 tons/ha) (Table 2).

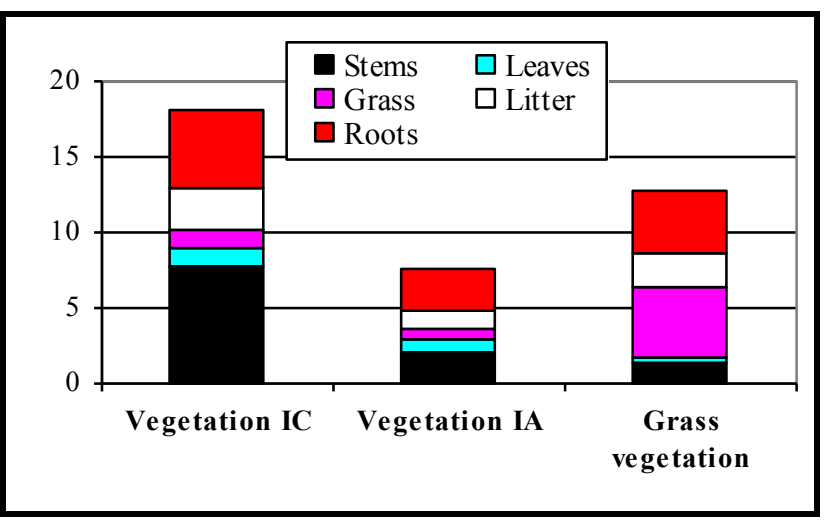

Figure 4: The structure of carbon volume accumulated in the vegetation in Cam Pha city, Quang Ninh Province

\subsection{Establishing carbon stock baseline}

The data used to set up the carbon stock baseline include the carbon volume accumulated in biomass of the vegetation and time of measurement.

From data in Table 2, we modeled the carbon distribution over time for each type of vegetation. No increase in the carbon content accumulated in biomass of the vegetation, except in vegetation $I C$, was shown (Table 2).

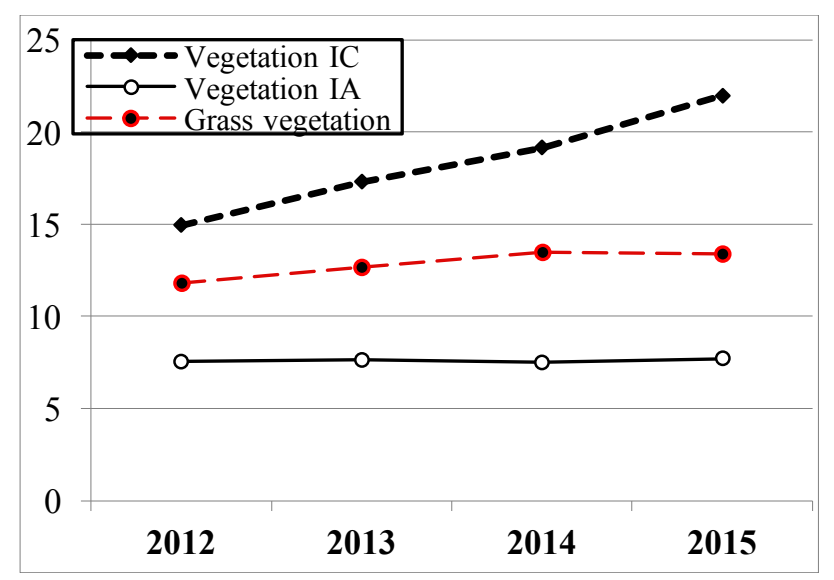

Table 5: Carbon baseline of vegetation in Cam Pha city, Quang Ninh province

In general, the carbon volume accumulated in vegetation of vegetation IC gradually increased overtime. Without any human interventions, after 4 years, the carbon volume stored this vegetation would increase by 7.04 tons/year (in 2013: 14.93 tons/ha; in 2015: 21.97 tons/ha). The vegetation of vegetation $I A$ and grass vegetation had a relatively stable carbon volume in their biomass (Figure 4).

Carbon stock baseline is one of the foundation to decide to invest in CDM afforestation/reforestation.

\section{Conclusion}

There was considerable difference in biomass of the degraded vegetation in Cam Pha city, Quang Ninh district. The vegetation IC had the largest biomass (fresh biomass: 78.70 tons / ha; dry biomass: 36.65 tons / ha), followed by grass vegetation (fresh biomass: 62.08 tons / ha; dry biomass: 25.67 tons / ha). Vegetation IA had the lowest biomass (fresh biomass: 33.73 tons / ha; dry biomass: 15.18 tons / ha). The ratio of dry biomass/fresh biomass (\%) of the vegetation had trend to increase. There were also differences in biomass structure and proportion of dry biomass per fresh biomass.

The average carbon volume accumulated in biomass of Vegetation IA reached 7.60 tons/ha, of Grass vegetation 12.84 tons/ha and Vegetation $1 C 18.33$ tons/ha. Among all types of vegetation in Cam Pha city, Quang Ninh province, carbon stock only increased in Vegetation IC (after 4 years, the accumulated carbon in Vegetation IC's biomass being 21.97 tons/ha).

The degraded vegetation in Cam Pha city, Quang Ninh province is recommended to be exploited and used in accordance with following orientations: (i) Maintaining the natural rehabilitation of the vegetation IC (ii) Planting trials to select species, varieties with high adaptability to grow on the vegetation of vegetation IA and grass vegetation; (iii) In case of lacking financial and human resources, firstly, protecting the vegetation to make use of its carbon accumulation and protection functions (from soil degradation, soil erosion and soil washout).

\section{References}

[1] Ban, N.T (1997) Handbook to reference and identification of the families of Angiospermae. (Magnoliophyta, Angiospermae) in Vietnam, Agriculture Publishing House, Hanoi.

[2] Ministry of Agriculture and Rural Development (2009), Circular no. 34/2009/TT- BNNPTNT, dated $10 / 6 / 2009$

[3] Brown, J. and Pearce, D. W (1994), "The economic value of carbon storage in tropical forests, in J.Weiss (ed)", The economics of Project Appraisal and the Environment, Cheltenham: Edward Elgar, pp 102 123.

[4] Ho, P.H (1991-1993), An illustrated flora of Vietnam, Volume I - III, Montreal, Canada.

[5] Trieu, D. T. (2010), Studying the ability of carbon fixation of Pinus massoniana Lamb and Pinus merkusii jungh et de plantations as a basis to determine the forest enviromental value according to CDM in Vietnam. PhD thesis. 